\title{
Impact of COVID-19 on Cashew Price and Cashew Producers' Income in Côte d'Ivoire: A Case Study in Five Departments
}

\author{
$N^{\prime}$ Banan Ouattara ${ }^{1,2}$, Clékaman Maïmouna Koné ${ }^{3} \&$ Xueping Xiong ${ }^{1}$ \\ ${ }^{1}$ College of Economics and Management, Huazhong Agricultural University, Wuhan, China \\ ${ }^{2}$ Centre Suisse de Recherches Scientifiques en Côte d'Ivoire, Abidjan, Côte d'Ivoire \\ ${ }^{3}$ Ministère de l'Agriculture et du Développement Rural, Direction des Cultures de Rente, Abidjan, Côte d'Ivoire \\ Correspondence: Xueping Xiong, College of Economics and Management, Huazhong Agricultural University, \\ No.1, Shizishan Street, Hongshan District, Wuhan, Hubei 430070, China. Tel: 86-131-0071-3981. E-mail: \\ xxp@mail.hzau.edu.cn
}

Received: May 20, 2020

Accepted: June 29, $2020 \quad$ Online Published: July 15, 2020

doi:10.5539/jas.v12n8p117

URL: https://doi.org/10.5539/jas.v12n8p117

This research was funded by the Fundamental Research Funds for the Central Universities, China (Grant No. 2662020JGPY005).

\begin{abstract}
In Côte d'Ivoire, cashew has become an important cash crop. Nevertheless, Côte d'Ivoire's cashew relies on the international market, with more than $90 \%$ of the production exported as raw nuts. The 2020 commercialization campaign started a few days after the outbreak of COVID-19 in China, which spread worldwide. This work assesses the impact of this pandemic on the cashew price and cashew producers' income in Côte d'Ivoire. We used the cashew price database over ten weeks in five cashew production areas and an interview-guided to collect the data. We used the Producer Price Index (PPI), descriptive statistic, and theoretical analysis of the income forecasting for data analysis. Results reveal that the lack of funds resulting from the fear of investors has caused a gradual drop in prices since February. This decrease has been more severe when restriction measures have been enforced. The purchase of cashews even stopped in some localities of the study areas. Compared to the first week of the campaign, the COVID-19 pandemic has reduced cashew producer income hugely to $50 \%$ in the sixth week and to $37.5 \%$ in the ninth and tenth weeks of our observation. Nonetheless, institutional factors such as the lack of control have also contributed to prices decrease. As recommendations, in the short-run, some resilience strategies such as subsidizing the local cashew market should be set up by the authorities. In the mid-term, the country should strengthen the cashew commercialization chain. In long-run, the local cashew transformation should be prioritized instead of raw nuts commercialization.
\end{abstract}

Keywords: cashew nut, Covid-19, marketing, income

JEL Classification: Q02, Q11, Q13

\section{Introduction}

The cashew tree (Anacardium occidentale) is a tropical plant native from Brazil, introduced to Asia and Africa by European explorers (N. Oliveira, C. Mothé, M. Mothé, \& L. Oliveira, 2019). Since its introduction, cashew has spread widely, and these continents (Africa and Asia) have become the centre of cashew production today (Aliyu, 2012). World production of cashew nuts is concentrated in two major regions of the world (SouthEastern Asia and West Africa). In 2015, West Africa and South-Eastern Asia together produced around 90\% (45\% each) of the world's raw cashews (Rabany, Rullier, \& Ricau, 2015). Specifically, the world's largest producers of cashews to date are Vietnam, Indian, and Côte d'Ivoire. According to statistics from the Food and Agriculture Organization (FAOSTAT, 2018), the production per ton of these countries was estimated at 2663 885; 785925 and 688000 in Vietnam, India, and Côte d'Ivoire, respectively. Raw nuts, cashew kernels, and cashew nut shell liquid are the cashew products traded on the international market (Aremu \& Akinwumi, 2014). Nowadays, cashew is a vital cash crop for millions of farmers, the majority of whom are small-scale farmers. In Africa, the contribution of cashew nut to Gross Domestic Product (GDP) and foreign exchange earnings is important for many cashew producing nations (Adeigbe, Olasupo, Adewale, \& Muyiwa, 2015; Aliyu, 2012). 
Besides its economic value, cashew nut has a variety of medicine and health care functions (Gong et al., 2016; Jalali et al., 2020).

In Cote d'Ivoire, the cashew tree was introduced in the late 1920s by the French colonial state in the context of reforestation programs. Indeed, in view to stop the advancing desert and fight against erosion, this tree was promoted in Savannah areas. In the 1970s, cashew has had an economic value and became a cash crop in view to increase household incomes in the North of Côte d'Ivoire (Bassett, 2017). In 1972, the Ivoirian government created the state company SOVANORD (Company for the Development of Northern Cashew) to boost the cultivation and marketing of cashew nut (Soro et al., 2011). Over the years, Côte d'Ivoire's cashew nut production has increased considerably following the rise in world cashew nut prices (Figure 1). Today, the cashew sector is the most dynamic in the centre and north regions of Côte d'Ivoire, surpassing the traditional export culture of cotton in terms of production volumes and revenues export (Mariam, 2018; Koffi \& Oura, 2019). Currently, cashew represents the third cash crop exported by the country after the cocoa and rubber. According to the Inter-Professional Fund for Research and Agricultural Council (FIRCA, 2018), foreign exchange generated by nuts cashew exports was estimated at 591.285 billion West African CFA franc (FCFA) in 2018. Nowadays, this commodity is a crucial resource for the livelihood of smallholder farmers (Koffi \& Oura, 2019; Monteiro et al., 2017; Ruf, Kone, \& Bebo, 2019). Income-generated by cashew nut plays a substantial role for the small producers by allowing them to invest in agricultural inputs (fertilizer, herbicide, labour, etc.), to build houses, to reimburse credit, and ensure their food security (Bassett, 2017). In central and northern Côte d'Ivoire, cashew income allows farming households to provide for their basic needs, such as the cost of schooling for children, health, food, and clothing, thus, facilitating their integration into society. For instance, in the city of Odienné, thanks to cashew income, the rate of children schooling and medical care of households have increased from $25 \%$ to $76.17 \%$ and from $20.09 \%$ to $87.16 \%$, respectively (Sinan \& Abou, 2016).

However, Côte d'Ivoire' cashew nut depends massively on the international market (Figure 1). Presently, the country exports more cashew nuts than any other country worldwide. The correlation between cashew production and exports is high (0.95), as shown in Figure 1. More than $90 \%$ of cashew production is exported in raw nuts to Vietnam, India, and Brazil; thus, less than $10 \%$ of cashew production is processed locally. This reliance on the international market exposes Ivorian cashew prices to global market fluctuation. As a result, the cashew market in Côte d'Ivoire is potentially fragile to an external macroeconomic shock. Additionally, the coronavirus (COVID-19) is one of these macroeconomic shocks. Indeed, in Côte d'Ivoire, the campaign of cashew nut commercialization begins officially in February and ends in June. Thus, the 2020 commercialization campaign was formally launched (February $6^{\text {th }}$ ) a few days after the outbreak of COVID-19 in Hubei province, China.

Moreover, the first case of coronavirus in Côte d'Ivoire was recorded on March $11^{\text {th }}, 2020$. This fatal virus is disturbing the whole world economy. COVID-19 inadvertently affected the financial markets and the global economy (Nicola et al., 2020). Global financial markets and global stock indexes have plunged. In their study, McKibbin and Fernando (2020) have concluded that in the case where COVID-19 develops into a global pandemic, the global economic costs of this shock can go up quickly. Unfortunately, on March $11^{\text {th }}$, this disease was classified by the World Health Organization (WHO) as a worldwide pandemic. For many reasons, the Covid-19 cannot be compared to other outbreaks (SARS, Ebola disease) and other global crises, like the 2008 financial crisis (Fernandes, 2020). Indeed, COVID-19 is a global pandemic. In addition, the supply and demand chains are simultaneously disrupted. Unlike events such as climate change that are much slower moving, or localized disasters that create spillover and market reactions, the COVID-19 pandemic is causing a direct global destructive economic impact that is present in every area of the globe (Goodell, 2020). The extent of the COVID-19 impact could probably differ according to the country, the economic sectors, and the economic actors. One of the concerns we would like to understand is the impact of the COVID-19 on the agricultural sector and smallholder farmers in developing countries. Therefore, it seems relevant to elucidate this concern empirically. This paper intends to assess the impact of COVID-19 on the price of cashew and the income of cashew producers in Côte d'Ivoire. Investigating the impact of this unpredictable shock will provide policymakers with some insights for better response and good forecasting for the future.

The remainder of the article is divided as follows: Section 2 is focused on the review of some empirical studies. Section 3 presents the actors of cashew chain in Côte d'Ivoire. Section 4 deals with the methodology used in this study. Sections 5 and 6 are concerned with the results and discussion, respectively. Finally, section 7 concludes and highlight the policy implications. 


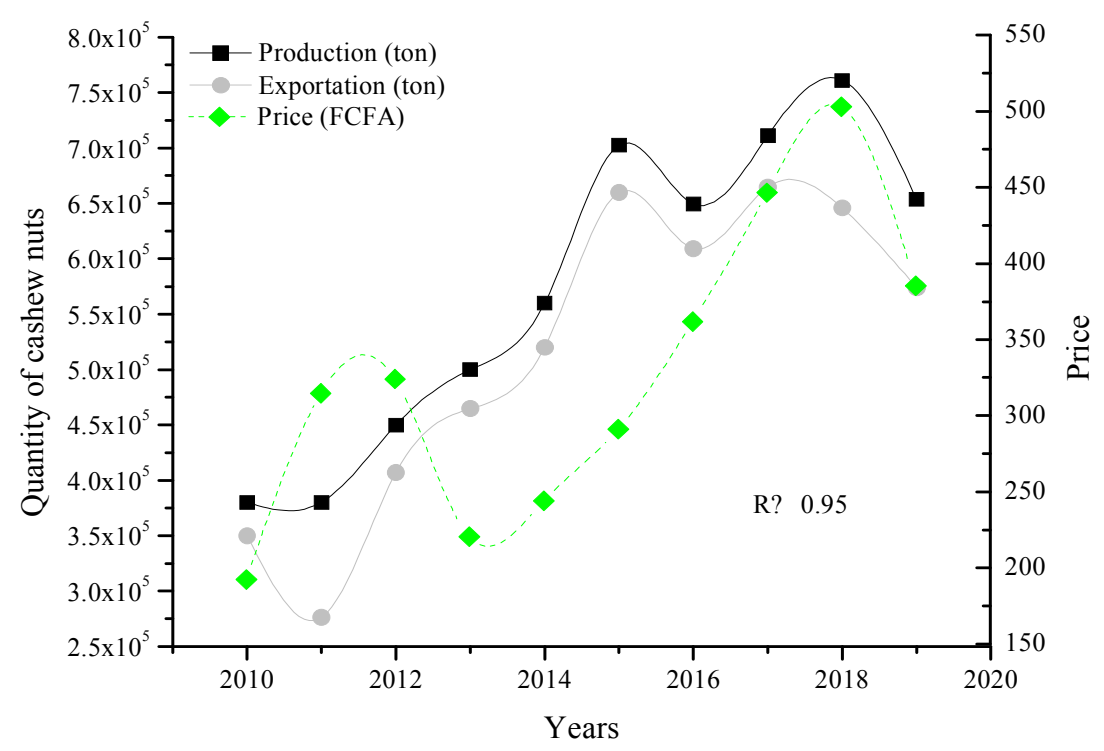

Figure 1. Cashew nut production, export, and price in Côte d'Ivoire from 2010 to 2019

Source: By the authors, with the data of FIRCA.

\section{Literature Review on the Economic Costs of Diseases}

In the wake of viral infections, numerous studies have been carried out to assess the loss or the economic impact of these diseases. These studies have been carried out in areas where the diseases have appeared or spread. In this part, we summarize some of them. Following the outbreak of SARS from November 2002 to August 2003, Chou, Kuo, and Peng (2004), Hai, Zhao, Wang, and Hou (2004), and Siu and Wong (2004) have measured the economic impact of this virus in China, Hong-Kong and Taiwan, respectively. Chou et al. (2004) found that in a short-run SARS wreaked losses to Gross Domestic Product (GDP) of the service and manufacturing sectors of $0.67 \%$ in Taiwan, $0.20 \%$ in mainland China, and $1.56 \%$ in Hong Kong. Hai et al. (2004) reported a significant impact of SARS on China's tourism sector. Due to the SARS epidemic, China's income from foreign and domestic tourism has decreased by about $50-60 \%$ and $10 \%$, respectively. Similarly, Siu and Wong (2004) underscored the adverse effects of SARS on the demand side by showing that local consumption and services related to tourism and air travel were severely affected in the short run in Hong-Kong.

Recently, the outbreak of the Ebola Virus Disease (EVD) in three West African countries (Liberia, Guinea, and Sierra-Leone) has disrupted economic sectors. In Liberia, Bowles, Hjort, Melvin, and Werker (2016) found a sharp decline in economic activity and jobs nationwide during EVD. The authors noted a more substantial drop in economic activity in the capital of Liberia, Monrovia. In the report on crop and food security assessment in Liberia, the Food and Agriculture Organization and World Food Programme (FAO \& WFP, 2014) found that border closures, quarantine measures, and other restrictions following EVD have gravely disrupted the marketing of goods, including agricultural commodities. In the same vein, Action Against Hunger (UK, 2015) has appraised the impact of EVD on food security and livelihood. The results showed that the outbreak of Ebola had caused a significant shock to the food and agriculture sector in Liberia. The spread of the EVD disrupted agricultural market chains and adversely affected the revenues derived from agricultural export commodities. Furthermore, this disease caused the loss of buyers for agricultural products resulting in the loss of perishable products and incomes for farmers. Figuie (2016) has examined the impact of EVD through seven market chains (rice, cassava, horticultural products, palm oil, domestic animal products, bush meat, and cocoa) in Guinea, Sierra Leone and Liberia. The findings showed that the Ebola epidemic disrupted the functioning of regional agricultural market chains, thus contributing to reducing farmers' incomes. Nevertheless, the severity of EVD impact on prices differed according to the agricultural chain. The prices for exportation crops such as cocoa decreased since the EVD outbreak interrupted international trade. Meanwhile, the price of local rice rose since rice importation was disrupted by the EVD. By studying the impact of the Ebola disease in Liberia, Guinea, and Sierra-Leon, Famine Early Warning Systems Network (FEWS NET, 2017) argued that the agriculture sector was hit the hardest in all three countries. The significant impacts of the Ebola disease were the loss of agricultural labour, the reduction of agricultural production, trade restrictions, and reduction of incomes from trade. The 
disruption of the farming sector has weakened farmers' livelihoods by significantly reducing their revenues and exposing them to food insecurity. Similarly, Gatiso et al. (2018) have reported the negative impact of the EVD epidemic on crop production of farm households in Liberia. This situation has exacerbated the problem of food insecurity throughout the country. Also, De la Fuente, Jacoby, and Lawin (2019) noticed that fear of congregating in groups disrupted worker mobilization and led to severe labour shortages, thus depressing rice production and, ultimately, rural welfare in Liberia.

Although the previous studies have given us insights about the economic impact of virus diseases, especially in the agricultural sector, this does not forbid us to investigate the prevailing situation for several reasons. Firstly, unlike previous virus diseases, the COVID-19 has classified as a pandemic by the WHO, and it spread across worldwide. An early study on the economic cost of the COVID-19 has concluded that if this disease develops into a global pandemic, the economic costs could rise quickly (McKibbin \& Fernando, 2020). Secondly, to the best of our knowledge, this is the first time for Côte d'Ivoire and Ivorian to cope in real-time with a virus disease to this magnitude. Since this March $11^{\text {th }}$, the country has reported its first case of coronavirus. Therefore, restrictive measures have been taken by the authorities and have been strengthened as the number of coronavirus cases is increasing. Thirdly, the shock of COVID-19 coincides with the 2020 commercialization campaign of cashew, which started February 6th officially, and more than 90\% of Côte d'Ivoire's cashew is exported in raw cashew. Also, most of Côte d'Ivoire's cashew production is exported to two Asian countries (India and Vietnam). For instance, in 2018, 74\% and 24\% of Côte d'Ivoire's cashew were exported in Vietnam and India, respectively (FIRCA, 2018). In the meanwhile, these two countries are also in the top-three of World countries' cashew producers. Ultimately, it appears relevant to assess the impact the COVID-19 on Côte d'Ivoire agricultural sector, more specifically its impact on cashew nut price at farm gate and cashew producers' income.

\section{Actors of Cashew Nut Chain in Côte d'Ivoire}

The actors of Côte d'Ivoire's cashew chain can be classified into four (4) groups: producers, regulation structure, buyers, and processors. Côte d'Ivoire's cashew production is ensured by around 400000 small farmers, with $83 \%$ of males and $17 \%$ of females (Ducroquet, Tillie, Louhichi, \& Gomez-Y-Paloma, 2017). The total size of farms is estimated at 3 million hectares, with size varying in a majority from 1 to 4 ha per producer (Mariam, 2018). However, the average size of farms can vary widely depending on the density of the population in the area, and some producers also have cashew farms of up to 20 hectares. Although the production of cashews is individual, it often happens that producers organize themselves in a cooperative for the marketing of cashews. Cashew producers are also involved in food crops such as rice, yam, maize, peanuts, cassava, and cash crops such as cotton, particularly in the North part.

In terms of institutional, the cashew chain is regulated by the Cotton and Cashew Council (CCA). The CCA is state-owned created in 2013 with the aim to structure and promote both cotton and cashew sectors. In particular, this structure focuses on technical support to producers, their organization, and the local processing of cashew production. The guaranteed minimum prices (field price, store price, and export price) are set by the CCA and professionals in the sector. These prices are valid for three months and can be revised (Ducroquet et al., 2017).

The cashew market in Côte d'Ivoire is segmented in several sub-actors. The first sub-actors are the exporters of raw nuts and processed nuts. At this step, we have trade societies, which include Ivorian organizations and Ivorian subsidiaries of Indian societies, and also producer cooperatives, which must be tremendous and theoretically able to negotiate the sale of their cashew products with some international traders directly. Second, we have wholesalers who are in contractual relationships with exporters. Wholesalers pre-fund some buyers to purchase a quota of cashew nut according to the area. And finally, in the fourth stage, the buyers hire the services of the trackers who live in the localities (villages) of the production area and are closer to cashew producers. These actors, between cashew producers and exporters, are qualified as intermediaries. However, they occupy a strategic position and play a significant role in a proper cashew market functioning.

Regarding the processing step, this activity consists mainly of peeling the cashew nuts to extract kernels before exporting (Sinan \& Abou, 2016). Although this step increases the added value of the product, the cashew nut processing in Côte d'Ivoire remains marginal (less than 10\%). For instance, in 2018, only 9\% of Côte d'Ivoire cashew was processed (FIRCA, 2018).

Besides these actors, there are some partner structures to the cashew chain, such as the Inter-Professional Fund for Research and Agricultural Council (FIRCA), the National Support Agency for Rural Development (ANADER), the National Centre for Agronomic Research (CNRA) and so forth. 


\section{Methodology}

\subsection{Study Area}

The areas selected for this study were chosen based on relevant criteria. According to the CCA, cashew is produced in the centre and north part of the country, more specifically in nineteen (19) regions. These regions are divided into high production areas of cashew ( $>60000$ tons), average production area of cashew (20 000 tons $<$ cashew production $<60000$ tons), and low production area of cashew ( $<20000$ tons). Based on this information, the choice of our study areas should represent all of the cashew production regions in Côte d'Ivoire in order to take into account the differences (distance from the port of Abidjan, area at the border with another country, another cash crop, unities of cashew processing, etc.) that may exist between these regions. Therefore, five departments have been selected as areas of this study (Figure 2). According to the last report of the national census of farmers and farms carried out by the Food and Agriculture Organization and Côte d'Ivoire's ministry of agriculture and rural development (2019), agriculture is the main activity of the population in these areas. Both food crops and cash crops are grown.

Bondoukou and Katiola belong to a high production region of cashew, the Gontougo, and Hambol regions, respectively. These cities are home to cashew processing units. In the area of Bondoukou, in addition to cashew nut, cocoa and coffee are grown but in a low quantity, and yam is the most popular food crop with more than $60 \%$ of the national production. While in Katiola, the cotton is grown, and the main food crops are rice, maize, yam, and cassava, peanut, and vegetables. Korhogo and Odienné are located in an average production region of cashew, the Kabagougou, and Poro regions, respectively. There are also some cashew processing units. In the area of Korhogo, we have some major cash crops such as cotton and mangoes. Rice, maize, peanut, millet, and vegetables are the food crops of the area. In Odienné, we also have cotton, mangoes, yam, rice, maize, and soybean as other crops. The city of Zuenoula is located between the Forest and Savannah area and belongs to a low production region of cashew, the Marahoué region. In addition to cashew crop, cocoa and sugar cane are other cash crops. In terms of food crops, we have rice, cassava, plantain, yam, and vegetables.

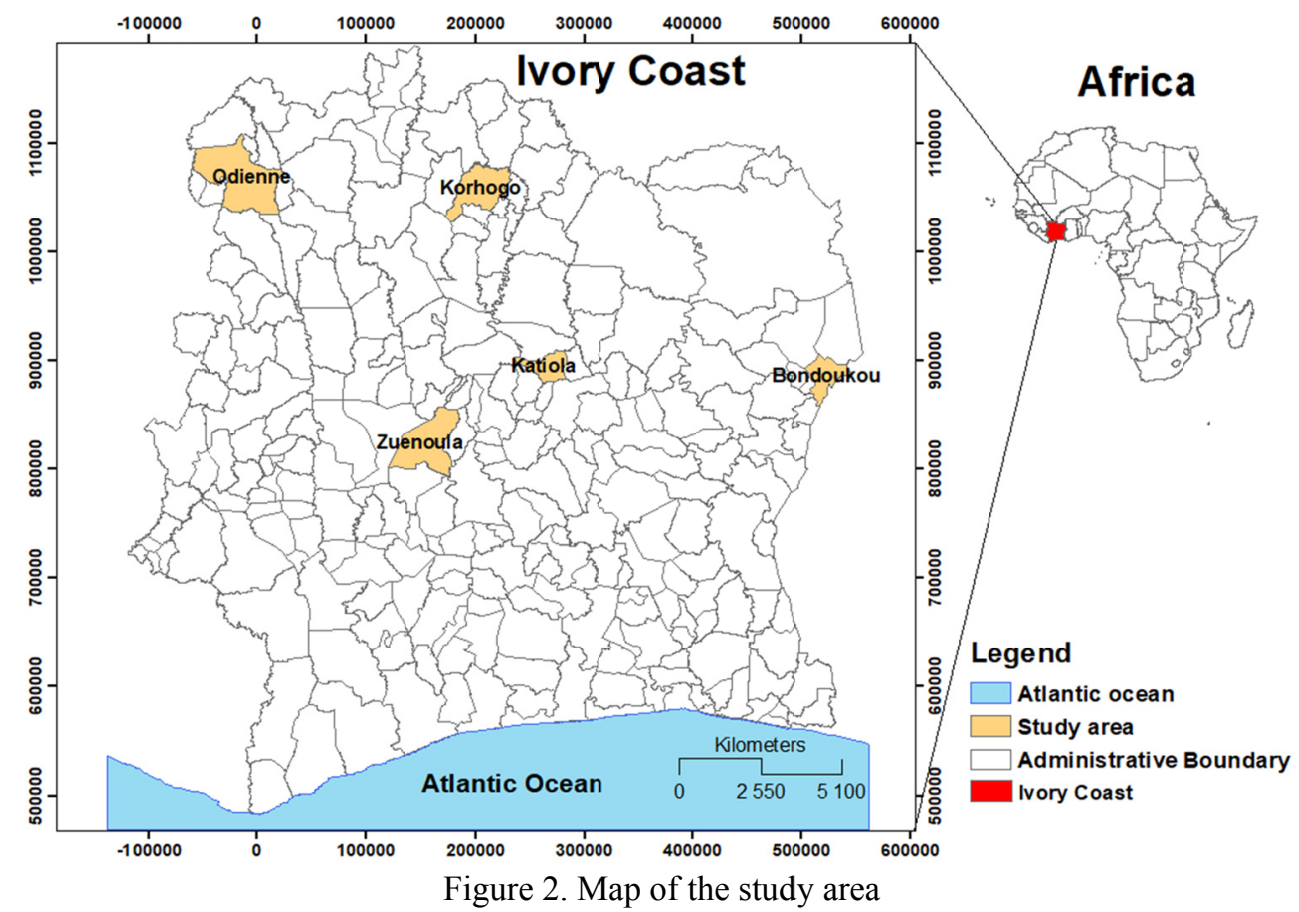

Source: By the authors.

\subsection{Data Collection and Analysis}

Quantitative and qualitative data were used in this study. Our database refers to cashew prices on the period of February $6^{\text {th }}$ to April $16^{\text {th }} 2020$. This period was divided into ten weeks. Practically, since the first week of February, a textbook to register the weekly prices of the kilogram of cashew has been opened in each area of the 
study. Two main actors were involved in the weekly price report (cashew producers and trackers). The trackers are buyers (men or women) who are closer to producers and in the front line in cashew purchasing. The weekly price report was supervised by an extension agent. This approach allowed us to harmonize the cashew price, which can vary across villages in the same area, and even according to the buyers (Soro et al., 2011). Finally, a face-to-face interview-guided focusing on the reasons for price fluctuation was applied to both producers and buyers. Due to some constraints (unavailability of cashew producer database, lack of time and money), we employed a non-probability sampling method. A priori sampling method was applied to select cashew producers while a snowball sampling method was used to select cashew buyers. Based on the information provided by Côte d'Ivoire's ministry of agriculture and rural development, we selected six (06) cashew producers per department. The latter were heads or managers of cashew producers' cooperatives. And then, with their aid, we constructed the sample of cashew buyers ( 06 buyers per department). Therefore, the total sample size was 60 respondents.

We used a price index and a descriptive statistic to analyze our data. To measure the general level of cashew nut price, we constructed a price index based on the Producer Price Index (PPI) by selecting a base period that corresponds to the starting point of the 2020 cashew campaign $\left(\mathrm{P}_{0}=400 \mathrm{FCFA}\right)$. The PPI is a price index that represents the changes in the selling prices received or paid by the producers, excluding indirect taxes. There are two main types of PPI (Akçay, 2011; Khan, Su, Tao, \& Chu, 2018). On one hand, the PPI can be output-oriented. That is, it measures the price indices of goods sold by producers. And on the other hand, it can be input-oriented. In this case, the PPI reflects changes in the prices paid by producers for raw materials or production factors. The current study focuses on the first one, i.e., output PPI. The PPI is computed by dividing the current prices received or paid by producers of a representative basket of goods by their prices in some base period (year, month, week) multiplied by 100. Based on the PPI's definition, our Cashew nut Producer Price Index (CPPI) can be formulated as follows:

$$
\mathrm{CPPI}_{\mathrm{t}}=\frac{\mathrm{P}_{\mathrm{t}}}{\mathrm{P}_{0}} \times 100\left\{\begin{array}{c}
\mathrm{CPPI}_{\mathrm{t}}=\text { price index of cashew nut in period } \mathrm{t} \\
\mathrm{P}_{\mathrm{t}}=\text { cashew nut price in period } \mathrm{t} \text { in FCFA } / \mathrm{kg} \\
\mathrm{P}_{0}=\text { cashew nut price in the base period in FCFA } / \mathrm{kg}
\end{array}\right.
$$

A theoretical analysis is used to assess the impact of fluctuating cashew prices on the income of producers. We used income equation (Equation 2) by assuming theoretically that producer income is constituted only by cashew production without any tax.

$$
R_{n, t}=P_{t} \times Q_{n}\left\{\begin{array}{c}
R_{n, t}=\text { Inocme of cashew producer } n \text { in period } t \\
P_{t}=\text { cashew nut price in period } t \text { in FCFA } \\
Q_{n}=\text { cashew nut quantity of producer } n
\end{array}\right.
$$

\section{Results}

\subsection{Evolution of Prices in Study Areas and Reasons for Price Variation}

To interpret data in a meaningful manner, we used index numbers with an index reference of value equal to 100 and the base price in the first week of February (Appendix A). As Figure 3 shows, during the ten weeks, there is a decrease in the price of the cashew nut compared to a value of 100 , except in the city of Katiola, where during the third week (W3), there was no price change. In the date of the first case of COVID-19 in Côte d'Ivoire and the date of declaration of the Coronavirus disease as a global pandemic by the WHO, on March $11^{\text {th }}$ (line A on Figure 3), the prices decreased to 81.25 points in Bondoukou, 75 points in Katiola and Zuénoula, 68.75 points in Odienné, and 62.50 points in Korhogo relative to a value of 100. On March $16^{\text {th }}$, when the first restrictive measures to curb the spread of COVID-19 were taken by the authorities (line B, W6), the price drop was enormous in all the cities of the study. This can be seen in Figure 3 with steeper slopes. The prices decreased to 50 points in four cities and 56.25 points in Zuénoula relative to a value of 100 . The percentage variation in the cashew price from week 5 to week 6, using the price index in each area is $20 \%$ in Korhogo, $25 \%$ in Zuenoula, $27.27 \%$ in Odienné, $33.33 \%$ in Katiola and $38.46 \%$ in Bondoukou. In the seventh week, prices remained unchanged in three cities compared to the previous week (W6) and decreased to 43.75 points in Korhogo and Odienné relative to a value of 100 . In week 8 , after the second restriction measures following by the lockdown of Abidjan (line C), on March $29^{\text {th }}$, the biggest city of the country, prices have decreased to more than 50 points relative to a value of 100, except the price in Katiola which was still unchanged compare to weeks 6 and 7 . Finally, prices have remained constant over the last two weeks of our observation, with a decrease to 37.5 points relative to a value of 100 in all study areas. 
Following the quantitative data, we pushed our analysis further by collecting qualitative data. We gathered the point of view of cashew producers and buyers on the main reasons for the variation in prices of cashew nuts by asking them the following open question: What are the reasons for the variation in prices this year, according to you? As indicated in Figure 4, three main reasons are mentioned by both producers and buyers: The lack of control, the COVID-19, and the lack of funding. The lack of control on the part of the regulatory structure (CCA) of the cashew sector leads to non-compliance with the price floor. Nevertheless, the different groups of actors are not unanimous about this reason. This factor was cited by $66.67 \%$ of producers, while a few buyers $(6.67 \%)$ have mentioned it as a reason. In contrast, both actors are unanimous on the COVID-19 pandemic as another reason for the drop in prices. The COVID-19 disease was mentioned by $60 \%$ of producers and $80 \%$ of buyers. Finally, the lack of funding also is pointed out as another reason by $40 \%$ of cashew producers and $86.67 \%$ of cashew buyers.

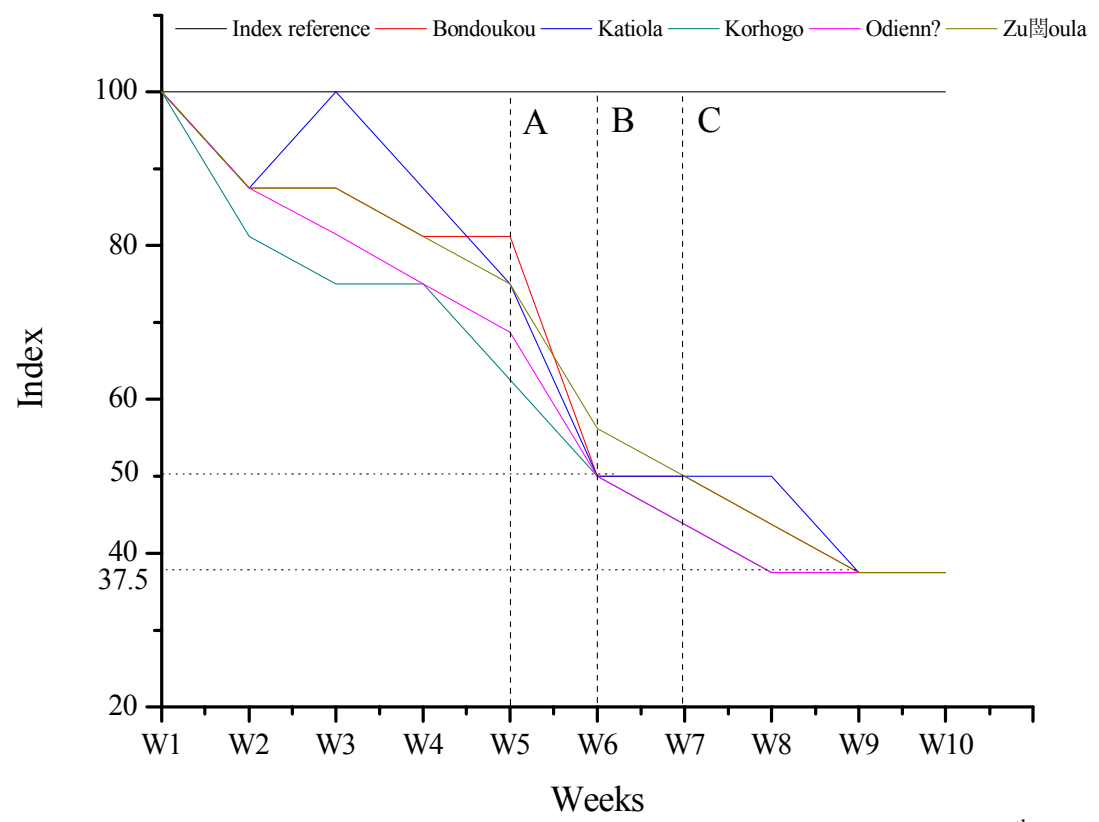

Figure 3. Weekly percentage change in Cashew nut Producer Price Index (February $6^{\text {th }}$-April $16^{\text {th }}, 2020$ ) Source: By the authors, with survey data.

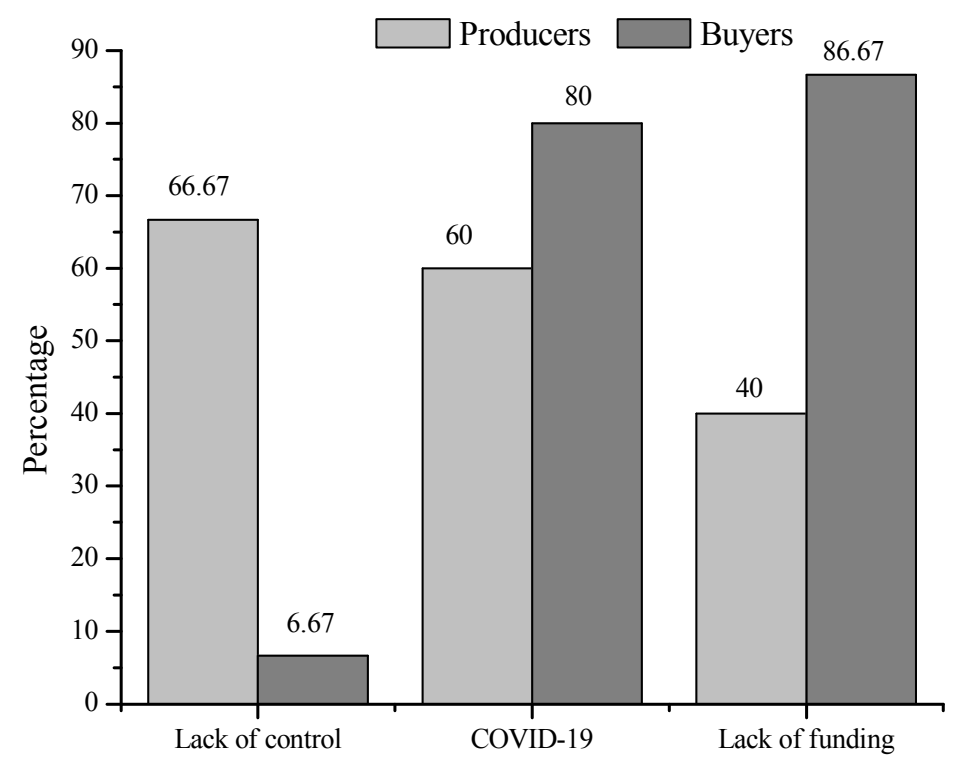

Figure 4. Reasons for price decreasing according to the view of actors

Source: By the authors, with survey data. 


\subsection{Impact on Producers' Income}

The Cashew prices fluctuation has an undeniable impact on cashew producer income. To assess this impact, we theoretically estimated the income derives from the cashew by considering three dates. The first point corresponds to the reference date with the price floor of 400 FCFA. The second point corresponds to the sixth week, i.e., the week of the first restriction measures enforcement with the price of 200 FCFA in the majority of study areas. And finally, the third point corresponds to the last week (W10) of our observation, with a price of 150 FCFA. As shown in Figure 5, the income of a cashew producer at the first point will be multiplied by half at the second point, and by three-eighth at the third point. This means that compared to the reference point, a cashew producer will have his cashew income cut in half and five-eighths at the second point and the third point, respectively, given the same quantity of cashews. For instance, for a quantity of 1 ton of cashew nut, a producer's income is $400000 \mathrm{FCFA}, 200000 \mathrm{FCFA}$, and $150000 \mathrm{FCFA}$ at the reference point, second point, and third point, respectively. The gap of income between the reference point and the other two points is shown in Figure 5 below.

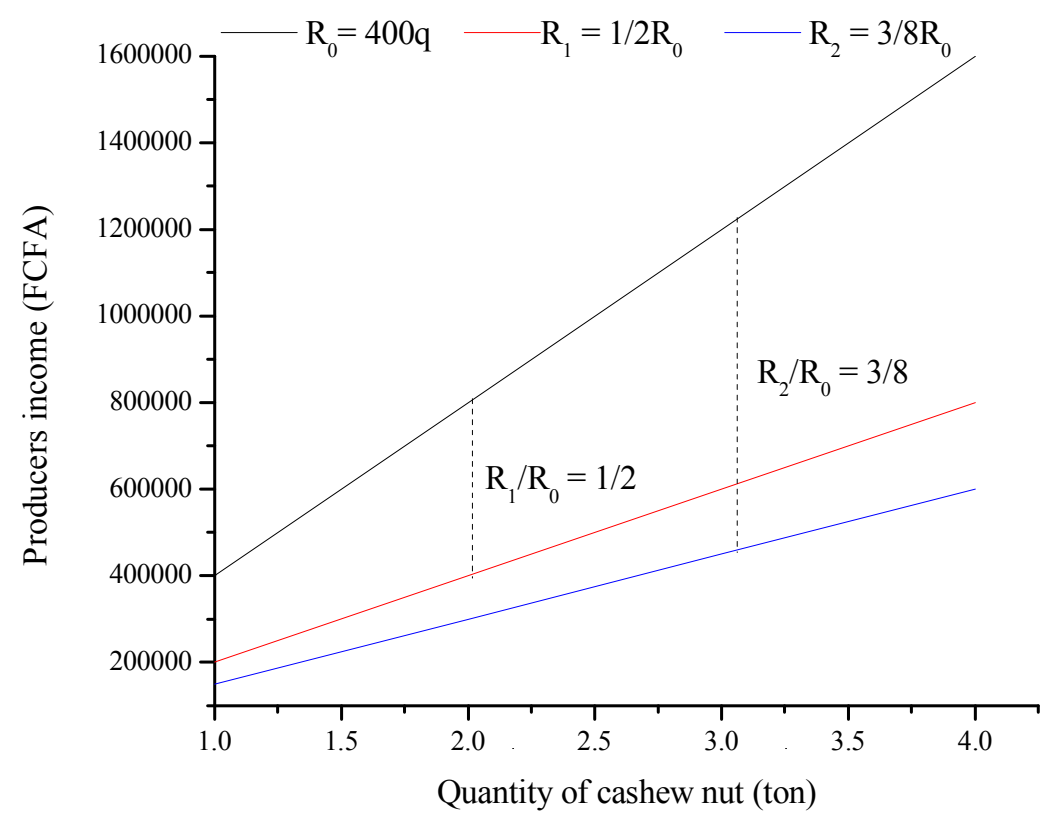

Figure 5. Change in cashew income following a consecutive change in price

Source: By the authors, with survey data

\section{Discussion}

Our study has shown that the price of cashew nut has known important fluctuations since the beginning of the campaign. Although the decrease in prices started in the second week of February, i.e., well before the first case of coronavirus in the fifth week (March), prices decreased more sharply as soon as the COVID-19 pandemic has appeared in Côte d'Ivoire. Indeed, since the first case of COVID-19 was recorded in Côte d'Ivoire, the authorities have taken restrictive measures such as travel ban, closure of air, land and sea borders, and the lockdown of the biggest city, Abidjan. These restrictive measures, including the travel ban, the closure of the sea borders, and the lockdown of Abidjan, which has the country's largest port, have probably disrupted and blocked cashew marketing channels. Some buyers of cashews may be overwhelmed by raw cashews since they cannot export it.

Moreover, the disruption of marketing channels increases transaction costs such as transport costs and storage costs of buyers who keep purchasing the cashew in villages. All these supplementary costs may have been deduced to the cashew price resulting in the drop in the purchase price. This finding is in line with previous studies (FAO \& WFP, 2014; Figuié, 2016). In Liberia, FAO and WFP (2014) argued that all restrictions measures taken to fight the EVD had disrupted the marketing of agricultural commodities. Figuie (2016) reported that during the EVD in Guinea, Sierra Leone, and Liberia, the regional agricultural market chain was disrupted, and prices for exportation crops such as cocoa decreased since the Ebola outbreak interrupted trade. 
The decrease in the price of cashew before the first case of coronavirus in Côte d'Ivoire could also be the indirect impact of COVID-19. Indeed, this pandemic started in January in Asia (China), and Côte d'Ivoire's cashew nut is exported in raw nuts to India and Vietnam. Most of the exporters are Asian operators. Consequently, the fear of COVID-19 would have dissuaded and impeded certain investors who became cautious in terms of investing funds abroad for the purchase of cashew nuts. As mentioned previously by McKibbin and Fernando (2020), this disease that has become a world pandemic has pushed the whole world economy in recession due to the lack of investments. Based on this study, we could infer that the lack of funds that has been mentioned by producers and buyers (Figure 4) as one of the reasons for the drop in prices of cashew nuts is directly correlated with the COVID-19. This is corroborated by the stopped of cashew purchases in some localities of the study area. One buyer we surveyed disclosed, "This year, the Indian investor with who I work did not come yet. Currently, I use my small fund to buy around 20 tons of products to keep it with the expectation that after this crisis, I will be able to re-sell it to make some profit. I will stop buying very soon because I have no more funds". Actually, in Côte d'Ivoire, most local buyers work with/for an international investor by being an intermediary or guide in the rural cashew market. Local buyers are more familiar with the local market and the cashew production areas. The lack of funds or international investors on the local cashew market leads to an imbalance between cashew supply and cashew demand (supply greater than demand). Thus, the few local buyers on the market apply prices below the reference price, especially as the financial needs of cashew producers push them to run after buyers.

In addition to the COVID-19 pandemic, it is important to highlight the lack of control as another factor of the cashew price drop in Côte d'Ivoire. In the rural cashew market of Côte d'Ivoire, we can find several intermediaries, as mentioned previously. Some intermediaries such as trackers who are closer to the producer and in front line do not comply with the price floor. Due to the lack of the regulator control, they apply a price lower than the reference price in view to obtain a margin that constitutes their salary or in order to compensate for the transport costs, especially in remote areas. Although the structure in charge of the cashew sector conducts awareness programs before each cashew marketing campaign, there are still some gaps. The intervention of the control structure is not systematic so that when inconsistencies are reported, it takes time before a solution is found. However, the prompt intervention of the structure in case of non-compliance with the price floor makes it possible to restore this price. This is the case in the Katiola area where, after reporting the non-compliance with the floor price, the intervention of the structure has compelled the buyers to apply the normal price in the third week (Figure 4).

The impact of the COVID-19 on cashew price causes a huge loss in terms of cashew income. As demonstrated theoretically, cashew producers could lose half or five-eighth of their income compared to the reference point. The likelihood of having a large number of cashew producers facing this loss of income is high. In fact, in Côte d'Ivoire, the marketing of nuts cashew peaks in March and April. This period also corresponds to the major agricultural activities in Côte d'Ivoire, so the financial needs of farmers are enormous. Farmers' investments in agricultural inputs (seeds, fertilizers, herbicides), ploughing, and hiring labour are urgent and cannot wait. Besides, some cashew producers must repay debts contracted the previous season and pay for the labour used to maintain the cashew plantation. All these reasons constrain nuts cashew producers to sell their products to the first comer with incomes lower to what they expected. Our findings bear rich parallels to those Action Against Hunger (UK, 2015) and FEWS NET (2017), who reported that the outbreak of Ebola had reduced significantly the revenues derived from agricultural export commodities in Liberia, Guinea, and Sierra-Leon.

\section{Conclusion and Policy Implication}

To date, cashew represents the third cash crop exported by Côte d'Ivoire after the cocoa and rubber. In addition to generating foreign exchange for the country, this crop is a key source of income for many small farmers, especially in the centre and north areas. Nonetheless, Côte d'Ivoire's cashew price is exposed to international market fluctuation. This year, the commercialization campaign started with the outbreak of coronavirus (COVID-19) disease. Like all countries, Côte d'Ivoire has enforced several restrictions measures to deal with this virus. This study aimed to assess the impact of the COVID-19 on the cashew price and the income of cashew producers in five production areas in Côte d'Ivoire.

Our results show that prices of cashew have decreased gradually since February due to the lack of funds resulting from the fear of both internal and international investors. This decrease has been more noticeable when the first case was reported in the country and the control measures enforced by the government since these measures have disrupted cashew marketing channels. Compared to the first week, the COVID-19 pandemic has reduced cashew producer income considerably to $50 \%$ in the sixth week and to $37.5 \%$ in the ninth and tenth 
week. However, institutional factors such as the lack of control by the regulator have also contributed to the fall in prices.

Following these findings, we suggest that in the short-run, policymakers should set up some resilience strategies such as subsidizing the local cashew market. These actions should consist of purchasing the cashew nut from producers at affordable prices in order to guarantee their income. In the mid-term, the authorities should reinforce the cashew commercialization chain. This could consist of strengthening the control and reducing intermediaries in the commercialization chain. Also, policymakers should develop e-business, especially cross-border e-commerce, as well as exploit the agri-business process enterprise for cashew's value chain. Moreover, they should increase the capability of storages innovated with low price inside the country. In the long run, the country should prioritize local cashew transformation instead of raw material commercialization. On one hand, this could increase the added value of the product. And on the other hand, the good capacity of the processing could widen the internal market of cashew. Hence, this would significantly reduce the influence of international exporters of raw nuts.

Our study has analyzed the impact of COVID-19 on only one commodity and in a relatively short period compared to the extent of this pandemic. However, this novel study provides insights of the effect of this global pandemic on cashew price and cashew producers' income in Côte d'Ivoire. Further researches, including more commodities (both exportable and non-exportable commodities), should be carried out.

\section{Acknowledgements}

The authors gratefully acknowledge the College of Economics and Management, Huazhong Agricultural University, and the Fundamental Research Funds for the Central Universities, China for funding this research. We are also grateful to all Ivorian actors involved in this study (cashew producers and buyers in the study area, Extension Agents of the National Agency for Rural Development Support). The authors warmly thank the following people for their technical support: Ali Mohamed El Yamine, Conan Mermoz, Coulibaly Lenikpoho Karim, and Zongo Abel Wend-Soo.

\section{References}

Adeigbe, O. O., Olasupo, F. O., Adewale, B. D., \& Muyiwa, A. A. (2015). A review on cashew research and production in Nigeria in the last four decades. Scientific Research and Essays, 10(5), 196-209. https://doi.org/10.5897/sre2014.5953

Akçay, S. (2011). The Causal Relationship between Producer Price Index and Consumer Price Index: Empirical Evidence from Selected European Countries. International Journal of Economics and Finance, 3(6), 227-232. https://doi.org/10.5539/ijef.v3n6p227

Aliyu, M. O. (2012). Genetic Diversity of Nigerian Cashew Germplasm. Genetic Diversity in Plants, June, 163-184. https://doi.org/10.5772/32892

Aremu, M. O., \& Akinwumi, O. D. (2014). Extraction, Compositional and Physicochemical Characteristics of Cashew (Anarcadium occidentale) Nuts Reject Oil. Asian Journal of Applied Science and Engineering, 3(2), 227-234. https://doi.org/10.15590/ajase/2014/v3i7/53573

Bassett, T. J. (2017). Le boom de l'anacarde dans le bassin cotonnier du Nord ivoirien. Afrique Contemporaine, 3, 59-83. https://doi.org/10.3917/afco.263.0059

Bowles, J., Hjort, J., Melvin, T., \& Werker, E. (2016). Ebola , jobs and economic activity in Liberia. J Epidemiol Community Health, 70(3), 271-277. https://doi.org/10.1136/jech-2015-205959

Chou, J., Kuo, N., \& Peng, S. (2004). Potential Impacts of the SARS Outbreak on Taiwan's Economy. Asian Economic Papers, 3(1), 84-99. https://doi.org/10.1162/1535351041747969

De la Fuente, A., Jacoby, H. G., \& Lawin, K. G. (2019). Impact of the West African Ebola Epidemic on Agricultural Production and Rural Welfare Evidence from Liberia (Issue June). https://doi.org/10.1596/ 1813-9450-8880

Ducroquet, H., Tillie, P., Louhichi, K. et Gomez-Y-Paloma, S. (2017). L'agriculture de la Côte d'Ivoire à la loupe: Etats des lieux des ilières de production végétales et animales et revue des politiques agricoles (EUR 28754 FR). https://doi.org/10.2760/126254

FAO \& WFP. (2014). Crop and food security assessment-Liberia.

FAO/Ministère de l'Agriculture et du Développement Rural. (2019). Recensement des Exploitants et Exploitations Agricoles (REEA) 2015-2016 (Vol. 2, p. 72). Abidjan. 
FAOSTAT (Food and Agricultural Organization Statistical Division). (2018). Statistical Year book. Retrieved from http://www.fao.org/faostat/en/\#data/QC

Fernandes, N. (2020). Economic effects of coronavirus outbreak (COVID-19) on the world economy. SSRN, 3557504, 0-29. https://doi.org/10.2139/ssrn.3557504

FEWS NET. (2017). Ebola and Livelihoods: The effect of the Ebola virus on household livelihoods in Guinea, Liberia, and Sierra Leone. Retrieved from https://fews.net/sites/default/files/documents/reports/Ebolaand Livelihoods_20170630.pdf

Figuié, M. (2016). Impact of the Ebola virus disease outbreak on market chains and trade of agricultural products in West Africa. FAO.

FIRCA. (2018). La filière du progrès. Magazine d'Information du Fonds Interprofessionnel Pour la Recherche et Le Conseil Agricoles, 1, 1-56.

Gatiso, T. T., Ordaz-Németh, I., Grimes, T., Lormie, M., Tweh, C., Kühl, H. S., \& Junker, J. (2018). The impact of the Ebola virus disease (EVD) epidemic on agricultural production and livelihoods in Liberia. PLoS Neglected Tropical Diseases, 12(8), 1-17. https://doi.org/10.1371/journal.pntd.0006580

Gong, J., Xia, W., Fu, Y., Huang, H., Zhang, F., \& Liu, Y. (2016). A Review on the Cashew Nut Shelling Techniques. Journal of Applied Science and Engineering Innovation, 3(4), 133-138.

Goodell, J. W. (2020). COVID-19 and finance: Agendas for future research. Finance Research Letters, 35. https://doi.org/10.1016/j.frl.2020.101512

Hai, W., Zhao, Z., Wang, J., \& Hou, Z.-G. (2004). The Short-Term Impact of SARS on the Chinese Economy. Asian Economic Papers, 3(1), 57-61. https://doi.org/10.1162/1535351041747905

Jalali, M., Karamizadeh, M., Ferns, G. A., Zare, M., Moosavian, S. P., \& Akbarzadeh, M. (2020). The effects of cashew nut intake on lipid profile and blood pressure: A systematic review and meta-analysis of randomized controlled trials. Complementary Therapies in Medicine, 102387. https://doi.org/10.1016/ j.ctim.2020.102387

Khan, K., Su, C., Tao, R., \& Chu, C. (2018). Is there any relationship between producer price index and consumer price index in the Czech Republic? Economic Research-Ekonomska Istraživanja, 31(1), 1788-1806. https://doi.org/10.1080/1331677X.2018.1498007

Koffi, Y. S., \& Oura, K. R. (2019). Les facteurs de l'adoption de l'anacarde dans le bassin cotonnier de Côte d'Ivoire. Cahiers Agricultures, 28(24). https://doi.org/10.1051/cagri/2019025

Mariam, O. G. (2018). Analyse de la dynamique de l'offre de noix brutes de cajou en Côte d'Ivoire: Uune application par l'approche autorégressif à retards échelonnés (ARDL). European Scientific Journal, 14(34), 292-306. https://doi.org/10.19044/esj.2018.v14n34p292

McKibbin, W. J., \& Fernando, R. (2020). The global macroeconomic impacts of COVID-19: Seven scenarios. CAMA Working Paper No. 19/2020. https://doi.org/10.2139/ssrn.3547729

Monteiro, F., Catarino, L., Batista, D., Indjai, B., Duarte, M. C., \& Romeiras, M. M. (2017). Cashew as a high agricultural commodity in West Africa: Insights towards sustainable production in Guinea-Bissau. Sustainability, 9(9), 1-14. https://doi.org/10.3390/su9091666

Net, F. (2017). Ebola and Livelihoods: The effect of the Ebola virus on household livelihoods in Guinea, Liberia, and Sierra Leone (Issue June).

Nicola, M., Alsafi, Z., Sohrabi, C., Kerwan, A., Al-Jabir, A., Iosifidis, C., ... Agha, R. (2020). The socio-economic implications of the coronavirus pandemic (COVID-19): A review. International Journal of Surgery, 78. https://doi.org/10.1016/j.ijsu.2020.04.018

Oliveira, N. N., Mothé, C. G., Mothé, M. G., \& Oliveira, L. G. de. (2019). Cashew nut and cashew apple : a scientific and technological monitoring worldwide review. Journal of Food Science and Technology, 1-10. https://doi.org/10.1007/s13197-019-04051-7

Rabany, C., Rullier, N., \& Ricau, P. (2015). General trends and country profiles: Analysis of cashew production, processing and trade in Africa. The African cashew sector in 2015.

Ruf, F., Kone, S., \& Bebo, B. (2019). Le boom de l'anacarde en Côte d'Ivoire: Transition écologique et sociale des systèmes à base de coton et de cacao. Cahiers Agricultures, 28(21). https://doi.org/10.1051/cagri/ 2019019 
Sinan, A., \& Abou, N. K. (2016). Impacts Socio-Economiques de la Culture de l'anacarde dans la Sous-Prefecture d'odienné (Côte d'Ivoire). European Scientific Journal, 12(32), 369-383. https://doi.org/ 10.19044/esj.2016.v12n32p369

Siu, A., \& Wong, Y. C. R. (2004). Economic Impact of SARS: The Case of Hong Kong. Asian Economic Papers, 3(1), 62-83. https://doi.org/10.1162/1535351041747996

Soro, D., Dornier, M., Abreu, F., Assidjo, E., Yao, B., \& Reynes, M. (2011). The cashew (Anacardium occidentale) industry in Côte d'Ivoire: Analysis and prospects for development. Fruits, 66, 237-245. https://doi.org/10.1051/fruits/2011031

UK, A. A. H. (2015). Ebola in Liberia : Impact on Food Security and Livelihoods (Issue March).

\section{Appendix A}

\section{Cashew nut price per city over ten weeks}

\begin{tabular}{|c|c|c|c|c|c|c|c|c|c|c|}
\hline \multirow{2}{*}{ Week } & \multicolumn{2}{|c|}{ Bondoukou } & \multicolumn{2}{|c|}{ Katiola } & \multicolumn{2}{|c|}{ Korhogo } & \multicolumn{2}{|c|}{ Odienné } & \multicolumn{2}{|c|}{ Zuenoula } \\
\hline & Price & $C P P I^{*}$ & Price & $C P P I^{*}$ & Price & $C P P I^{*}$ & Price & $C P P I^{*}$ & Price & $C P P I^{*}$ \\
\hline W1 & 400 & 100 & 400 & 100 & 400 & 100 & 400 & 100 & 400 & 100 \\
\hline W2 & 350 & 87.5 & 350 & 87.5 & 325 & 81.25 & 350 & 87.5 & 350 & 87.5 \\
\hline W3 & 350 & 87.5 & 400 & 100 & 300 & 75 & 325 & 81.5 & 350 & 87.5 \\
\hline W4 & 325 & 81.25 & 350 & 87.5 & 300 & 75 & 300 & 75 & 325 & 81.25 \\
\hline W5 & 325 & 81.25 & 300 & 75 & 250 & 62.5 & 275 & 68.75 & 300 & 75 \\
\hline W6 & 200 & 50 & 200 & 50 & 200 & 50 & 200 & 50 & 225 & 56.25 \\
\hline W7 & 200 & 50 & 200 & 50 & 175 & 43.75 & 175 & 43.75 & 200 & 50 \\
\hline W8 & 175 & 43.75 & 200 & 50 & 150 & 37.5 & 150 & 37.5 & 175 & 43.75 \\
\hline W9 & 150 & 37.5 & 150 & 37.5 & 150 & 37.5 & 150 & 37.5 & 150 & 37.5 \\
\hline W10 & 150 & 37.5 & 150 & 37.5 & 150 & 37.5 & 150 & 37.5 & 150 & 37.5 \\
\hline
\end{tabular}

Note. 1 FCFA $=0.0017 \$$ at time of the survey; * Authors' calculations.

\section{Copyrights}

Copyright for this article is retained by the author(s), with first publication rights granted to the journal.

This is an open-access article distributed under the terms and conditions of the Creative Commons Attribution license (http://creativecommons.org/licenses/by/4.0/). 